\title{
$\boldsymbol{\nabla}$ Artikkeli
}

\section{Valokuva, materiaalisuus, representaatio}

\begin{abstract}
Kameran sulkimen avautuessa kuvauksen kohteesta tulevat valonsäteet kohtaavat filmin tai kuvakennon. Syntyy materiaalinen jälki, josta erinäisten vaiheiden jälkeen saadaan aikaiseksi näkyvä valokuva. Kutsun tuota jälkeä valokuvan materiaaliseksi ytimeksi, koska se on valokuvan kaikkien muiden materiaalisuuksien perusta. IIman sitä kuva ei ole valokuva. Artikkeli pohtii ytimen materiaalisuutta ja sen suhdetta semioottiseen indeksisyyteen.

Lähtökohtana on, ettei materiaalinen ydin vain kuorru semioottisilla merkityksillä eri käytännöissä. Se on toiminnallinen artefakti, joka muodostaa tarjoumia (affordansseja) monille eri käytännöille, eikä vähiten tutkimukselle itselleen. Lopuksi tarkastelen, millaisen tarjouman materiaalinen ydin muodostaa valokuvatutkimuksen klassikolle, Roland Barthesin Valoisalle huoneelle.
\end{abstract}

AVAINSANAT: valokuva, materiaalisuus, indeksisyys, toimijuus, Roland Barthes.

V

uonna 2012 julkisuuteen levisi Curiosity-luotaimen ottamia upeita valokuvia Marsin maisemista. Koska etäisyys naapuriplaneettaamme on 56-40o miljoonaa kilometriä, valokuvalta kestää jopa kaksikymmentä minuuttia ennen kuin se saapuu maan kamaralle. Tuona aikana se on olemassa vain sähkömagneettisena aaltoliikkeenä. Sillä ei ole tarkkaa paikkaa tai aikaa, eikä ihmisen aistijärjestelmä kykene siihen reagoimaan.

Marsin pinnalta lähtenyt entiteetti on digitaalinen tiedosto, joka sopivien teknologisten muunnosten jälkeen saadaan näkyväksi kuvaksi tietokoneen ruuduille, aikakauslehtiin tai vaikkapa t-paitoihin. Valokuvan materiaalisuudella on siis paljon erilaisia ulottuvuuksia, jotka niveltyvät kulttuurisiin käytäntöihin, näyttöihin ja painopintoihin. Materiaalisuuksien moninaisuus saattaa hämärtää sen tosiasian, että kaikkien nykyisten valokuvien tapaan myös kuvat Marsin pinnalta ovat fotonien jättämiä jälkiä kuvakennon diodeihin, joiden varaus muuttuu niihin osuneen säteilyn intensiteetin ja aallonpituuden mukaan. Vanhassa fotokemiallisessa valokuvassa sama jälki syntyy säteilyn aiheuttamista muutoksista filmin kemikaaleissa. Kutsun tätä säteilyn jättämää jälkeä valokuvan materiaaliseksi ytimeksi, koska se on kaikkien muiden valokuvan materiaalisuuksien edellytys. Ilman sitä kuva ei ole valokuva. ${ }^{1}$ 
Valokuva on tietenkin myös kuvallinen esitys kameran edessä olleesta näkymästä. Se on kaksiulotteiselle tasolle optiikan lakien mukaan projisoitunut kuva. Vaikka kuvallisuus on läsnä tässä artikkelissa, se näyttelee sivuroolia. Yritän ennen kaikkea ymmärtää valokuvan materiaalista ydintä ja sen toimintaa. Valokuvan materiaalisuudet tietenkin vaikuttavat siihen, miksi sen kuvallisuus koetaan niin vahvasti kuin se usein koetaan. Kuvallisuus puolestaan antaa materiaaliselle ytimelle visuaalisen hahmon. Ne konstituoivat toisiaan.

Usein materiaalista ydintä pidetään valokuvan aitouden takeena, joka erottaa sen esimerkiksi maalauksesta tai kirjoitetusta kielestä. Valoisan huoneen (1980) tunnetussa kohdassa Roland Barthes $(1985,82 ; 1980,120)^{2}$ muotoilee asian seuraavasti: "Maalaus voi olla tekevinään todellisuutta näkemättä sitä. Diskurssi yhdistelee merkkejä, joilla tietenkin on referentit, mutta nämä referentit voivat olla 'kuviteltuja', kuten useimmiten ovatkin. Päinvastoin kuin näissä jäljittelyissä, valokuvauksessa en voi koskaan kieltää, etteikö kohde olisi ollut paikalla." ${ }^{3}$ Voimme siis väitellä Marsista otettujen valokuvien tarkkuudesta tai todenmukaisuudesta, mutta keskustelu muuttuu mielettömäksi, jos emme oleta, että ne ovat ainakin olennaisilta osiltaan kameraan tallentuneita jälkiä naapuriplaneettamme maisemista.

Jos luemme Barthesia tarkasti, monessa kohden hän näyttää myös suovan valokuvalle jonkinlaista toimijuutta. Valokuva voi "pistää" (emt., 33, 49) tai "shokeerata" (emt., 38,57 ) ja joskus jopa katsoa "suoraan silmiin" (emt., 117, 172). Hän ei kuitenkaan tarkemmin erittele, mitä toimijuus on tai miten se suhteutuu valokuvan materiaalisuuteen. Seuraavassa avaan tätä problematiikkaa vastaamalla kolmeen kysymykseen. 1. Millainen on valokuvan materiaalinen ydin? 2. Miten se tavoitetaan semioottisesti? 3. Miten ymmärtää materiaalisen ytimen toimijuutta suhteessa Valoisaan huoneeseen? Artikkelini teema nivoutuu osaksi laajempaa, pääosin yhteiskuntatieteellistä keskustelua materiaalisuudesta ja objektien toimijuudesta. Uusmaterialismin (New Materialism) nimikkeen alla tutkijat ovat kiinnostunet niin orgaanisen ja epäorgaanisen suhteista, bioetiikasta ja biopolitiikasta kuin myös objektien tai esineiden roolista osana sosiaalisia järjestelmiä (Coole \& Frost 2010; vrt. Appadurai 1986; 2006; Latour 2005; Hahn 2012). Myös historiallisen materialismin lähtökohtia on arvioitu uudelleen (Edwards 2010), ja klassiset kysymykset biologian ja sukupuolen suhteista ovat myös ajankohtaistuneet uusin tavoin (Keane \& Rosengarten 2002; Ahmed 2008; Grosz 2010). Samalla semioottiset ja kulttuurintutkimuksen perinteeseen nojautuvat kuvatulkinnat ovat saaneet haastajansa erilaisista kuvan materiaalisuuteen, toimijuuteen ja moniaistisuuteen keskittyvistä analyyseistä (Edwards \& Hart 2004; Edwards 2009; Pink 2011). Kuten tuonnempana kuitenkin esitän, näiden tarkastelujen ongelmana on usein newtonilaiseen mekaniikkaan nojautuva käsitys materiasta, jonka kautta on vaikea päästä kunnolla kiinni sen enempää perinteiseen kuin digitaaliseen valokuvaan.

Luonnonobjektien tai valmistettujen artefaktien toimijuus on tietenkin erilaista kuin ihmisen, johon usein liitetään sellaisia määreitä kuin intentionaalisuus, vapaus, omintakeisuus, luovuus, kyky tehdä valintoja ja muuttaa toimintaympäristöä. Samalla tutkijat myös muistuttavat siitä, että niin yhteiskunnan rakenteet kuin ihmisen itsensä psyykkinen dynamiikka asettavat rajoja inhimillisen toiminnan omaehtoisuudelle 
(ks. esim. Barker 2003, 236; myös Giddens 1984; Žižek 1989). Materiaalisilla objekteilla ei tietenkään ole tietoisuutta eivätkä ne kykene intentionaaliseen toimintaan. Tästä huolimatta ne ovat toimijoita jossain rajoitetummassa mutta ei aina vähäpätöisemmässä mielessä. Ihminen ei esimerkiksi vain muokkaa ympäristöään rakentamalla, myös ympäristö muokkaa häntä asettamalla rajoja ja mahdollisuuksia toiminnalle. Joki voi mahdollistaa liikkumisen mutta myös muodostaa ylitsekäymättömän esteen. Ylimalkaan materiaaliset objektit tarjoavat inhimilliselle toimijalle erilaisia tarjoumia eli affordansseja, mahdollisuuksia kuvitella ja myös käyttää niitä eri tavoin (Gibson 1989; Lehmuskallio 2012). Ihminen voi "nähdä" kivessä painon, rakennusaineen tai aseen, mutta ruoaksi siitä ei ole. Analogisesti voidaan ajatella, että myös valokuvalla ja sen materiaalisella ytimellä on useita eri tarjoumia, joita sen materiaalisuus mahdollistaa tai jopa ohjaa.

Koska materiaalinen maailma historiallisesti edeltää kulttuurista, on luontevaa lähteä liikkeelle valon jättämästä jäljestä. Sen jälkeen siirryn indeksisyyden käsitteeseen, joka vie materiaalisen ytimen osaksi semiotiikkaa ja kulttuurista merkityksen muodostumista, signifikaatiota. Puolustan käsitystä valokuvan materiaalisuudesta ja indeksisyydestä muutamia valokuvateorian "anti-indeksisiä" kantoja vastaan. Lopuksi vedän langat yhteen ja tarkastelen valokuvan materiaalista toimijuutta ja jännitteistä luonnetta representaationa erityisesti Valoisan huoneen kontekstissa.

\section{Materiaalinen ydin: jälki}

Kameran sulkimen avautuessa kuvauksen kohteesta lähteneet valonsäteet kohtaavat filmin valoherkät kemikaalit. Syntyy latentti kuva, joka tarvitsee vielä kehittämisen muuttuakseen silmin havaittavaksi negatiiviseksi kuvaksi. Tapahtuma kertoo jotain visuaalisuuden ja valokuvan välisestä suhteesta: valokuvan olennaisista materiaalisista ominaisuuksista voidaan tarvittaessa keskustella puuttumatta lainkaan kuvan visuaalisiin ulottuvuuksiin. Barthes $(1985,86 ; 1980,126)$ toteaa saman omalla tavallaan: "Usein on sanottu, että valokuvauksen keksivät taidemaalarit (jättämällä sille perinnöksi rajauksen, albertilaisen perspektiivinsä ja camera obscuran optiset ominaisuudet). Mutta minä sanon: ei, kemistit sen keksivät."

Valokuva itsessään on tuotettu materiaalisin välinein: filmin, kameran ja optiikoiden avulla. Myös kuvauksen kohteet ovat materiaalisia, koska filmille syntyy jälki vain sellaisista esineistä, jotka kykenevät heijastamaan, taittamaan tai säteilemään valoa. Valon itsensä materiaalisuus on nykyfysiikan tietämyksen mukaan monimutkainen kysymys. Sitä voidaan ymmärtää vain paradoksien kautta, koska valolla on sekä aaltomaisia että hiukkasmaisia ominaisuuksia. Massan sijaan kvanttimekaniikassa puhutaan epäjatkuvuuksista, epätarkkuusperiaatteesta ja tilojen lomittumisista. Valokvanteilla eli fotoneilla ei ole lepomassaa mutta kylläkin energiaa. Yleisesti voidaan sanoa, että fotonin energiatila on yksi valon materiaalisuuden muoto, mutta tällöin sana "materiaalinen" ei enää vastaa mitään totunnaista havaintoa tai käsitystä materiasta. (Auyang 1995, 128-129; Kallio-Tamminen 2008, 119-123.) Fotonien energialla on 
kuitenkin myös sanan perinteisessä mielessä materiaalisia vaikutuksia: koko maapallon elämä on riippuvainen fotosynteesistä. Toisaalta voimakas sähkömagneettinen säteily voi tuhota kaiken elämän. Valon vaikutuksesta myös negatiivissa tapahtuu materiaalisia muutoksia, kun sen kemikaalit absorboivat kuvauksen objekteista heijastuneet tai säteilleet fotonit.

Mutta mitä tapahtuu, kun perinteinen negatiivi korvautuu digitaalikameran kuvakennolla? ${ }^{4}$ Jotkut tutkijat näkevät digitalisoitumisen muuttavan valokuvan alati "immateriaalisemmaksi" (ks. esim Doane 2007, 143). Valokuvan materiaalisuuden kannalta kameran digitalisoituminen on kuitenkin monisyinen ilmiö. Digitaalisessa kamerassa kuva piirtyy valolle herkistä puolijohteista, fotodiodeista, koostuvalle kennolle. Kun kameran suljin avautuu, kuvakennon pinnalle muodostuu jälki. Fotonit absorboituvat diodeihin, synnyttävät vapaita elektroneja ja aiheuttavat jännitteen, jonka suuruus riippuu fotonien määrästä eli valon voimakkuudesta. Syntynyt signaali mitataan, vahvistetaan ja ajatetaan muuntimeen, joka analysoi sen digitaaliseksi koodiksi. (Jacobson ym. 2009, 191, 193-194.) Kennon pinnalle syntyvän kuvan valoisuuden vaihtelut kääntyvät siis jännitteen muutoksiksi, jotka puolestaan käännetään digitaaliseksi koodiksi. Kun valo jättää jälkensä kennon pinnalle, kuva ei vielä ole digitaalisessa muodossa. Digitalisointi tapahtuu välittömästi tämän jälkeen, jolloin myös yksittäisestä diodista lähteneen signaalin aika- ja paikkakoordinaatit säilyvät. Prosessin eri vaiheissa syntyy hävikkiä ja muunnoksista johtuvaa kohinaa, mutta digitaalinen tiedosto on mahdollista muuntaa takaisin kuvaksi, joka muistuttaa kennon pinnalle langennutta optista kuvaa. Digitaalikameran kennolle muodostunut analoginen ja jatkuva kuva on tavallaan säilötty epäjatkuvaan binaariseen koodiin.

Tämän artikkelin näkökulmasta on olennaista se, että sekä fotokemiallisessa että digitaalisessa valokuvauksessa fotonit aiheuttavat muutoksia materiassa, jotka tallennetaan ja prosessoidaan tavalla, josta ne on palautettavissa visuaaliseksi valokuvaksi. Ei ole syytä olettaa, että digitaalisen valokuvan syntyprosessi olisi jotenkin "immateriaalisempi" kuin perinteisen fotokemiallisen valokuvan. Digitaalisen ja perinteisen valokuvan materiaalisuudet ovat erilaisia, mutta alkavat muistuttaa sitä enemmän toisiaan, mitä syvemmälle aineen rakenteisiin uppoudutaan: valon jättämä jälki perustuu kummassakin tapatuksessa fotonien aiheuttamiin elektronien energiatilojen muutoksiin. Sekä digitaalisessa että analogisessa valokuvauksessa alkuperäinen jälki pitää vahvistaa ja muuntaa, jotta siitä ylimalkaan saadaan näkyvä kuva. Sekä latentti kuva että binaariseen tiedostoon koodattu jälki ovat ensi vaiheessa näkymättömiä ja vaativat joko kemiallisen tai algoritmeihin perustuvan prosessoinnin.

Väitteet immateriaalisuudesta ovat kuitenkin ymmärrettäviä, koska digitaalisuus yhdistetään helposti ohimenevyyteen ja keinotekoisuuteen. On hyvin helppo ottaa digitaalinen valokuva ja pyyhkiä se saman tien pois kameran muistista. Käytännössä jokaisen fotokaupan tiskiltä voi kuitenkin jo tällä hetkellä ostaa cd-rom-levyjä, joiden arvioidaan säilyttävän digitaalisen koodin noin sata vuotta. ${ }^{5}$ Kun otetaan huomioon rajattoman monistettavuuden koodin kestävyydelle tuoma etu, väitteet digitaalisen tiedoston huonommasta säilyvyydestä negatiiviin verrattuna alkavat menettää uskottavuuttaan. Periaatteessahan binaarinen koodi voidaan hakata vaikkapa peruskallioon. 
Digitaalisen valokuvan oletettu immateriaalisuus riippuu tietenkin myös siitä, mitä materialla tarkoitetaan. Yleisesti ajatellaan, että se on jotain käsin kosketeltavaa, kiinteää ja työstettävää. Esimerkiksi arkeologi Nicole Boivin (2008, 26-27) tarjoaa seuraavan määritelmän: "Materian piiriin voidaan lukea erilaiset objektit, ympäristöt, maisemat ja ruumiit - kaikki se, mikä ei ole abstraktia vaan käsin kosketeltavaa. Materiaalisuus on puolestaan sana, jota käytän luonnehtimaan materiaalisen maailman fyysistä puolta: maailmalla on ulottuvuuksia, se tarjoaa vastuksia ja pakkoja ja samalla mahdollisuuksia inhimilliselle toimijalle (tai organismille) juuri näiden fysikaalisten ominaisuuksiensa vuoksi." Myös harvat tutkimukset valokuvan materiaalisuudesta jakavat usein samanlaisen käsityksen. Esipuheessaan kirjaansa Photographs Objects Histories Elizabeth Edwards ja Janice Hart $(2004,3)$ kirjoittavat kuinka materiaalisuus viittaa "todellisiin fysikaalisiin objekteihin maailmassa, joka on ruumiillisesti koettavissa ei pelkästään näköaistin välityksellä vaan myös tuoksuina, kosketuksina ja ääninä”.

Kun valokuvaa tarkastellaan sen materiaalisuuksien kannalta, se ei enää siis puhuttele pelkästään näköaistia. Laadukkaalle kartongille painettu valokuva antaa tuntoaistille erilaisen vaikutelman kuin ilmaisjakelulehden sivulle painettu. Vanhat albumivalokuvat puhuttelevat usein paitsi aiheellaan myös tuoksullaan. Matkapuhelimessa laitteen paino ja tuntu käteen asettuu osaksi valokuvallista kokemusta. Valokuva voi myös olla samanlainen materiaalinen muisto kuolleesta ihmisestä kuin mikä tahansa hänelle kuulunut esine. Tällainen käsin kosketeltava materiaalisuus on tärkeä osa valokuvallisen representaation kokemista ja tarjoaa mielenkiintoisia polkuja tarkastella erilaisia valokuvauksen käytäntöjä.

Kiinteä materiaalisuus operoi kuitenkin newtonilaisen fysiikan maailmassa eikä anna mahdollisuuksia ymmärtää prosesseja, jotka liittyvät valokuvan materiaalisen ytimen muotoutumiseen ja sen fysikaalisiin ominaisuuksiin. Niiden ymmärtäminen vaatii siirtymää kvanttimekaniikkaan, mikä monimutkaistaa ja laajentaa materian käsitteen ja liittää sen erilaisiin energiatiloihin ja partikkeleiden liikkeisiin. On siis järkevää ajatella, että valokuvalla on useita erilaisia materiaalisuuksia ja olomuotoja: perinteinen negatiivi ja printti, flash-muisti tai vaikkapa Marsista maahan matkaava moduloitu sähkömagneettinen säteily.

\section{Semioottinen merkki: indeksisyys}

Semioottisesti orientoituneessa valokuvatutkimuksessa valon jättämää jälkeä hahmotetaan indeksisyyden käsitteellä. Tunnetuin indeksisyyden luonnehdinta löytyy Charles Sanders Peirceltä, joka kirjoittaa: "Voimme ajatella, että Merkki on Indeksi, kun se on fragmentti, joka on repäisty irti Objektista, joiden kummankin olemassaolo muodostaa yhden kokonaisuuden tai osan siitä" (Peirce 1965, 137 [2.231]). Hän jatkaa: "sikäli kun Objekti on vaikuttanut Indeksiin, sillä on jotain yhteistä Objektin kanssa ja juuri tässä suhteessa se viittaa Objektiin" (emt., 143 [2.247]). Valokuvat ovat hänen mukaansa "tuotettu sellaisissa olosuhteissa että ne on fyysisesti pakotettu vastamaan luontoa piste pisteeltä" (emt., 159 [2.281]). 
Peircen indeksisyyden käsite viittaa moniin muihinkin merkin ominaisuuksiin kuin materiaaliseen kausaalisuuteen, esimerkiksi osoittamiseen (ks. esim. Doane 2007; Laakso 2003, 88-136). Tällöin minkä tahansa kahden asian välillä voi olla indeksinen suhde, jos toinen jollain tavoin osoittaa toiseen. Tuuliviirin ja tuulen suhde on indeksinen, kuten myös kohteen ja sitä osoittavan nuolen. Tässä artikkelissa käsittelen indeksisyyttä vain materiaalisen kausaliteetin kontekstissa. Näen indeksisyyden nimenä prosessille, jonka seurauksena kuvauksen kohde jättää valon välityksellä materiaalisen jäljen filmin tai kuvakennon pinnalle. ${ }^{6}$

Siinä suhteessa kuin Peirce korostaa kausaalisuutta merkin ja sen objektin välillä, hänen käsityksensä indeksisyydestä on materiaalinen ytimiä myöten. Hän jopa sanoo, kuinka Indeksi on fragmentti, joka on "repäisty" (torn away) Objektista ikään kuin ne olisivat aikaisemmin olleet materiaalisesti yhtä.

Tämä ei tarkalleen ottaen pidä valokuvan kohdalla paikkaansa, koska kuvauksen kohteista tulleet fotonit, eivät kohteet itsessään, jättävät jäljen filmille tai kuvakennon diodeihin. Tosiasia on saanut muutamat tutkijat arvioimaan uudelleen indeksisyyttä valokuvan merkityksen muodostumisen kannalta (Snyder \& Walsh Allen 1975; Sonesson 2001; Hainge 2008; Winston and Tsang 2009).

Monet "anti-indeksiset" kannat tiivistyvät Göran Sonessonin ajattelussa. Hän (emt., 36) korostaa, kuinka "valokuva kannattaa ymmärtää suoraksi ja selkeäksi fotonien, siis kuvauksen kohteista tulevan valon, jättämäksi jäljeksi, ja vain epäsuoraksi ja abstraktiksi jäljeksi itse kuvauksen kohteista”. Hän summaa tämän merkityksiä signifikaatiolle: "Ymmärtääksemme valokuvan [- - ] merkityksen meidän ei tarvitse pohtia sen indeksisyyttä. Valokuva jatkaa merkityksen välittämistä riippumatta siitä, tiedämmekö sen olevan valo-kuva. Valokuvan indeksisyys todellakin on toisarvoinen ja erityisiin olosuhteisiin liittyvä kysymys." (Emt., 37.)

Vaikka Sonesson osuu oikeaan kausaalisen kytkennän "epäsuoruudesta", hänen argumenttinsa ei kuitenkaan kumoa valokuvan indeksisyyden materiaalista luonnetta, jossa kuvauksen kohteesta lähteneet energiakvantit faktisesti muokkaavat ja jättävät jäljen filmin tai kuvakennon pinnalle. Tämä yhteys ei ole mitenkään "abstrakti" vaan hyvin materiaalinen. Kannattaa myös huomata, että energia voi siirtyä ainakin kahdella tavalla. Normaalisti fotonit heijastuvat kohteen pinnalta, jolloin kohde koskettaa epäsuorasti säteilyn välityksellä kuvakennon pintaa. Mutta valo voi myös säteillä itse kohteesta. Kun kuvataan esimerkiksi hehkulamppua tai laskevaa aurinkoa, kameraan tulevat fotonit lähtevät suoraan hehkuvasta materiasta. Tällöin filmin tai kennon pinnalle absorboituneet fotonit ovat olleet myös fyysisesti yhtä kuvauksen kohtaan kanssa, ja - kuten Peirce totesi - "repäistyt" irti kohteestaan.

Hieman haasteellisempi Sonessonin (emt., 36) argumentti valokuvan indeksisyyden merkitystä vastaan tulee siitä, että katsoja ei koskaan voi olla varma siitä, mistä kuva on indeksi, koska "valokuva ei ole vain indeksi kohteista tai fotoneista vaan myös filmin ominaisuuksista, linssiryhmistä ja ylimalkaan valokuvalaitteesta sekä fotonien täyttämästä tilasta". Tähän voitaisiin vielä lisätä, että valokuva on myös indeksi ilman optisista ominaisuuksista: Marsin kaasukehä jättää erilaisen jäljen valokuvaan kuin maan. Kaikki tämä pitää paikkansa, mutta ei kuitenkaan horjuta sitä, että valokuva 
on indeksinen jälki myös kuvatuiksi tarkoitetuista objekteista. Kuvan aihe (sen intentionaalinen sisältö) on vain osittain sama asia kuin valokuvattu tila kaikkine mahdollisine substansseineen.

Kun ihmiset katsovat arjessaan valokuvia, he eivät yleensä mieti kuvan materiaalisuuden ulottuvuuksia. Näemme ennen kaikkea ikonisia, jotain esittäviä kuvia, emme "indeksisiä jälkiä". Näiltä osin Sonessonin anti-indeksinen kanta tulee osin ymmärrettäväksi. Kuvallisen aistimuksen pohjalla kuitenkin operoi hiljainen tuntemus siitä, että kuvatut objektit ja tilanteet ovat jättäneet jälkensä kameran kennolle. En väitä, että tuntemus on universaali, mutta se on erittäin todennäköinen osa valokuvallista kokemusta kulttuureissa, jossa valokuvalla on vankka asema. Indeksisyyden tuntu aktivoituu joka kerta kun ajattelemme, tiedostetusti tai tiedostamattomasti, valokuvaa tai olemme niiden kanssa tekemisissä. ${ }^{7}$

Gillian Rose kuvaa tuntemusta tutkimuksessaan Doing Family Photography (2010). Hänen haastateltavansa puhuivat läheistensä kuvista ikään kuin ne olisivat ihmisiä, joita kuvat esittävät (Rose 2010, 31-32). He eivät sanoneet, että "tämä kuva esittää isääni" vaan että "tässä on isäni". Voidaan tietenkin miettiä, olisivatko ihmiset valinneet samat sanat, jos kyseessä olisi valokuvan sijaan ollut piirros. Mistä tiedämme, kuinka paljon sanavalinnoista lankeaa indeksisyyden kuinka paljon kuvan visuaalisen esittävyyden, ikonisuuden varaan? Valokuvakokemuksessa on tietenkin mahdoton erotella näitä kahta. Ne sulautuvat toisiinsa. On kuitenkin selvää, että indeksisyys tuo valokuviin poikkeuksellista läsnäolon tuntua. Brittirunoilija Elizabeth Barret Browning kirjasi ylös tuntojaan valokuvasta 1843, vain neljä vuotta valokuvauksen virallisen keksimisen jälkeen:

Harras toiveeni on saada muisto kaikesta mikä tässä maailmassa on minulle rakasta. Eikä siinä ole yhdennäköisyys yksin arvokkainta - vaan siihen liittyvä läheisyyden tunne ja mielikuvat [--] se että hänen todellinen varjonsa on tallennettu kuvaan ikuisiksi ajoiksi! Nähdäkseni siinä on muotokuvien tosi pyhyys - eikä se ole suinkaan osoitus hirviömäisyydestäni, kuten kiivaat veljeni puolestaan väittävät, kun sanon että kernaammin ottaisin sellaisen muiston syvästi rakastamastani ihmisestä kuin kaikkien aikojen hienoimman taideteoksen. (Lainattu teoksessa Sontag 1984, 171.)

Koska indeksisyys on valokuvallisen representaation välttämätön edellytys, se toimii perustana valokuvan muille semioottisille funktioille, kuten ikonisuudelle. Peirce kirjoittaa kuinka "valokuvat, erityisesti välittömät sellaiset, ovat hyvin instruktiivisia, koska tiedämme, että ne ovat joiltain osin juuri sellaisia kuin esittämänsä objektit. Mutta tämä samankaltaisuus johtuu siitä, että valokuvat on tuotettu tilanteessa, jossa ne on fyysisesti pakotettu vastaamaan piste pisteeltä luontoa." (Peirce, 1965: 159 [2.281].)

Vaikka Peirce toteaakin, kuinka valokuvat ovat joiltain osin juuri sellaisia kuin esittämänsä objektit, niiden indeksisyyden ja ikonisuuden välillä ei ole mitään välttämätöntä suhdetta. Valokuva voi olla läpikotaisin indeksinen mutta samalla niin epäterävä, ettei kuvauksen kohteesta saa mitään selvää. Tällaisessakin tapauksessa indeksisyys kuitenkin motivoi hahmottamaan, josko kuvasta olisi löydettävissä jonkinlainen tunnis- 
tettava piirre. Indeksisyys ylläpitää käsitystä, että valokuva on kuitenkin kuva jostakin kameran edessä olleesta. Tämä on yksi valokuvan materiaalisen ytimen toimijuuden keskeinen piirre. Se tuo kohteen toisella tavalla läsnäolevaksi kuin esimerkiksi kirjoitettu teksti tai piirros. Voidaan ajatella, että erilaiset käytännöt tietenkin määrittelevät, miten tämä materiaalisen ytimen toimijuus realisoituu merkityksiksi ja merkityksellisyydeksi. Mutta yhtä hyvin voidaan ajatella, että materiaalinen ydin on tarjouma, johoin jokainen valokuvaa hyödyntävä käytäntö joutuu ottamaan kantaa.

\section{Levoton representaatio}

Millaista siis on valokuvan materiaalisen ytimen toimijuus?

Kenties kaikkein tunnetuin muotoilu löytyy André Bazinilta (1960, 7): "Ensimmäistä kertaa alkuperäisen objektin ja sen toisinnon väliin asettuu ei-inhimillinen toimija. Ensimmäistä kertaa kuva maailmasta muotoutuu automaattisesti, ilman ihmisen luovaa väliintuloa." Bazin viittaa itse asiassa koko valokuvausprosessin luonnonkaltaisuuteen, jonka monet valokuvauksen keksijät tunnistivat jo 1800-luvun alkuvuosikymmeninä. Esimerkiksi valokuvauksen tunnetuimmat keksijät Niépce ja Daguerre eivät pystyneet päättämään, kuka oikeastaan oli valokuvan todellinen tekijä: luonto vai itse valokuvaaja. Geoffrey Batchen $(1997,69)$ kuvaa elegantisti, kuinka nämä pioneerit hahmottivat valokuvan representaatioksi, joka "on samalla kertaa aktiivinen ja passiivinen, joka piirtää luontoa mutta antaa samalla luonnon piirtää itseään, joka yhtä aikaa heijastaa ja konstituoi kohteensa, joka poistaa erottelun kopion ja originaalin välillä, joka on yhtä aikaa osa luontoa ja kulttuuria".

Valokuva on oikeastaan erinomainen esimerkki "hybridistä objektista", joka on yhtä aikaa luontoa ja kulttuuria. Bruno Latourin (1993) mukaan olemme erilaisten hybridien ympäröimiä, mutta meidän on suhteellisen vaikea käsittää niiden toimintaa, koska luonto ja kulttuuri ovat meille käsitteellisiä vastakohtia. Tämä epistemologinen tila - jonka historiaan tässä ei ole mahdollisuutta paneutua seikkaperäisemmin - selittää varmaan osin valokuvauksen pioneerien hämmennystä. Samaa hämmennystä kuvastaa valokuvaaja Lewis Hinen kuuluisa tokaisu: "Valokuvat eivät valehtele, mutta valehtelijat voivat valokuvata." Suhteellisen helppoa on ymmärtää, että valokuvaajat voivat valehdella. Mutta jos yrittää ymmärtää, millaisesta toimijuudesta on kysymys silloin, kun "valokuvat eivät valehtele", joudutaan hankalien kysymysten ääreen. Tästä huolimatta jokainen valokuvakulttuurissa elänyt ymmärtää intuitiivisesti, mitä lause tarkoittaa.

Materiaalisen ytimen toimijuutta voi lähteä avaamaan pohtimalla itse representaation käsitettä, jolla on tietenkin paljon eri merkityksiä tieteenalasta riippuen. Yhteiskuntatieteilijät, filosofit tai vaikkapa valokuvatutkijat käyttävät representaation käsitettä tahoillaan mutta keskustelevat harvoin keskenään (ks. esim. Hall 1997; Deaux \& Philogène 2001; Webb 2009; Kella 2014, 146-154). Käsitteen alkujuuri löytyy latinan sanasta repraesentatio, joka viittaa muun muassa kuvailuun ja silmien eteen asettamiseen. Historian eri vaiheissa käsite on saanut paljon erilaisia vivahteita, mutta 
1400-luvulla se alkoi vastata nykyisin sille asettuvia merkityksiä. Representaatio alkoi viitata jonkun edustamiseen, toisen tilalla olemiseen tai jonkin kuvana tai muotona olemiseen. Vaikka edustamisen ajatus on vain yksi mahdollinen tapa ymmärtää representaatio, niin se on nykyään kaikkein yleisin. (Knuuttila \& Lehtinen 2010, 10-11.)

Representaation keskeinen ulottuvuus liittyy läsnä- ja poissaoloon. Tarja Knuuttila ja Aki Petteri Lehtinen (emt.) kirjoittavat, kuinka "jokin poissa oleva korvautuu jollain uudella läsnäolon muodolla. Uusi läsnä oleva edustaa tai esittää poissa olevaa - esimerkiksi mielessä oleva ajatus tai muisto rakastetusta edustaa kaipauksen todellista, poissa olevaa kohdetta. [- - ] Representaatio siis ymmärretään perinteisesti objektina, tilana tai ominaisuutena, jonka tehtävä on viitata johonkin ulkopuoliseen."

Gottfried Boehmin (2012, 17-18) tavoin on mahdollista ajatella, että läsnäolonpoissaolon problematiikka aktivoituu kaikissa kuvallisissa esityksissä. Maalauksen esittämä henkilö saattaa olla kuollut tai muualla, mutta maalaus suo poissa olevalle läsnäoloa, joka voi olla hyvin intensiivistä. "Kaikkein kaunein kuvan piirre on sen kyky antaa kasvot poissaolevalle ja luotamme poistuneelle ja jopa liittää hänen nimeensä näkyvyys ja läsnäolo", hän (emt., 18) kirjoittaa.

Tiiviissä tekstissään Boehm mainitsee valokuvan mutta ei pohdi sen erityisluonnetta representaationa. Valokuva on kuitenkin erilainen kuvallinen representaatio kuin maalaus tai piirustus, koska sen materiaalinen ydin tuo kuvauksen kohteen poikkeuksellisen läsnä olevaksi. Jos kuvauksen kohteesta emittoituneet fotonit piirtävät jälkensä kuvakennolle, jälkeä voidaan perustellusti pitää osana kuvauksen kohdetta. Fotonien heijastuessakin kohteen ja valokuvan välille muodostuu vahva kausaalinen sidos. Valokuva ei siis vain viittaa konventionaalisesti johonkin itsensä ulkopuoliseen kuvallisena representaationa, vaan "ulkopuolinen" on läsnä itse valokuvassa. Hieman kärjistäen, valokuvan katsoja ei oikeastaan tiedä kumpaa hän kokee, kuvauksen kohdetta vai representaatiota siitä.

Paradoksi voidaan siis kuvata seuraavalla tavalla:

1. Kun valokuva ymmärretään poissaolevaa kohdetta esittäväksi representaatioksi, materiaalinen ydin tekee kohteen hyvin läsnäolevaksi.

2. Kun valokuva ymmärretään läsnä olevaksi materiaaliseksi jäljeksi kohteesta, valokuva re-presentaationa saattaa kohteen poissaolevaksi.

Tästä syystä valokuva on aina epävakaa, levoton representaatio, jossa läsnä- ja poissaolo voivat vuorotella vaihduntakuvion tavoin. Kun läsnäolo näyttää vakiintuvan, poissaolo huuhtelee sen pois. Kun poissaolo pääsee voitolle, materiaalinen ydin muistuttaa kohteen läsnäolosta. Se viettelee valokuvallisen representaation leikkiin, jossa panoksena ei ole sen enempää tai vähempää kuin representaatio itse. Kameran mahdollistama ja valon piirtämä valokuvan materiaalinen ydin tuo koko ajan ongelmia kaikille yrityksille määritellä valokuvaa tai sen tapoja tuottaa merkityksiä. Materiaalinen ydin saattaa tukea läsnäolollaan valokuvan kuvallisesti viestimiä merkityksiä. Samalla läsnäolon- poissalon-dynamiikka tekee itse representaatiosta ristiriitaisen. Materiaalisuus ja signifikaatio elävät jännitteisessä tilassa. ${ }^{8}$

Valokuvallisen representaation läsnä- ja poissaolon dynamiikkaa voidaan myös pohtia suhteessa historiallisiin kuvakäsityksiin. Patrick Maynard (1983; 1997) tiivistää 
esiin kaksi suhtautumistapaa. Kuva voidaan nähdä kohteensa visuaalisena kuvauksena (description) mutta myös kohteensa manifestaationa (manifestation), eräänlaisena ilmentymänä. Ortodoksisen kirkon piirissä ja erityisesti sen ikonitaiteessa kuvat nähtiin eräänlaisina pyhän manifestaationa. Lähtökohta ei ollut niinkään pyhimysten tai tapahtuminen tarkka kuvaaminen kuin yhteyden- ja läsnäolon tunteen rakentaminen kuvan kokijan ja kuvatun asian välille. Lännen katolisen kirkon vaikutuspiirissä syntyneessä taiteessa kuvat esittivät puolestaan kohdettaan naturalistisesti. Niinpä läntisen kuvataiteen tai estetiikan piirissä ei ole oikeastaan koskaan voitu kunnolla ymmärtää ja käsitellä kuvan manifestoivia funktioita: olemme aivan liiaksi katsoneet kuvia niiden itsensä ulkopuolisten asioiden kuvaajina, siis representaatioina. Tämä on heijastunut myös kykyymme kokea vieraiden kulttuurien kuvastoja sikäli kun ne nojautuvat enemmän manifestaatioon kuin visuaaliseen, figuratiiviseen esittämiseen.

Maynardin jaottelua ei ehkä kannata ymmärtää absoluuttisesti, koska kumpikin suhtautumistapa on itse asiassa ratkaisu samaan vanhatestamentilliseen kieltoon valmistaa mitään kuvia jumaluudesta. Mutta jos ajattelemme representaatio-käsitteen historiallista muotoutumista nykyiseen merkityksiinsä, jossa tärkeää on siis representoidun poissaolo, niin ajatus kuvien manifestoivan funktion vähäisestä sijasta läntisessä kuvakäsityksessä vaikuttaa uskottavalta.

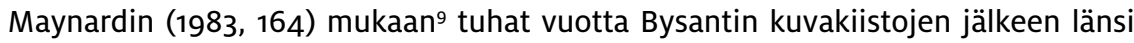
sitten törmäsi valokuvan keksimisen myötä "omaan manifestoivaan kuvaansa". Valokuvallisessa representaatiossa manifestoivat ominaisuudet vieläpä yhdistyvät tai ainakin voivat yhdistyä kuvallisen esittämisen optiseen tarkkuuteen. Tästä näkökulmasta katsottuna juuri materiaalisen ytimen liike on tehnyt valokuvasta mitä maagisimman ja runollisimman kuvan.

Valokuvan materiaalisen ytimen toimijuus tiivistyy siis sen kykyyn saattaa manifestoivan funktionsa kautta valokuvallinen representaatio epävakaaseen tilaan, jossa kuvauksen kohde on sekä läsnä että poissa. Tämä valokuvallisen representaation paradoksaalisuus on tosiasia, jonka jokainen valokuvan diskurssi ja käytäntö joutuu ottamaan tavalla tai toisella huomioon.

Sanottakoon, että toimijuuden myöntäminen materiaaliselle ytimelle ei ole kuitenkaan ongelmatonta, koska se voi johtaa helposti ylilyönteihin, jossa valokuva alkaa säteillä jonkinlaista maagista voimaa ympäristöönsä. Janet Wolff $(2010,14)$ varoittaa tutkijoita "animismista" ja "sosiaalisen haihtumisesta ilmaan". Hänen mukaansa "kuvilla (ja objekteilla) onkin 'voimaa' henkilökohtaisessa ja sosiaalisessa elämässä, mikä tarkoittaa, että niitä ylistetään/kauhistellaan/pelätään ja niin edelleen”. Mutta tämä voima "juontuu kulttuurista tai henkilökohtaisesta elämästä, se ei kumpua kuvista itsestään" (emt.). Kysymys erilaisten objektien tai kuvien toimijuudesta joutuu siis pujottelemaan kahden ääripään välistä. Objektien ja kuvien toimintaa ei voi redusoida ominaisuudeksi, jonka kulttuurinen ympäristö tai konteksti niille langettaa. Toisaalta niiden voimaa ei tule liioitella unohtamalla niiden kulttuurinen ja yhteiskunnallisiin käytäntöihin liittyvä signifikaatio. Jos kuvat tai objektit eivät ole toimijoita inhimillisessä tai animistisessa mielessä (vrt. Barker 2003, 236), niin millaista sitten on niiden toimijuus? 
Niin sanotun ekologisen psykologian kehittäjä James Gibson (1979, 127-143) tarjoaa ongelmaan yhden mahdollisen lähestymistavan. Hänen mukaansa niin materiaalinen ympäristö, esinemaailma kuin jopa toiset inmiset muodostavat eräänlaisia tarjoumia eli affordansseja. ${ }^{10}$ Luonnonobjektit tai artefaktit mahdollistavat joitain käyttöjä ja sulkevat muita pois. Autolla voi ajaa eteen ja taaksepäin, mutta sillä on hankalampi lentää. Puuta voi polttaa pesässä, mutta raketin polttoaineeksi siitä ei ole. Gibsonille tarjoumat sijoittuvat kulttuurin, subjektiivisen kokemuksen ja materiaalisen maailman välimaastoon ja - vaikkei hän sitä mainitsekaan - muistuttavat Latourin mainitsemia hybridejä objekteja. Tarjouma on yhtä lailla kulttuuria ja henkilökohtaista kokemusta kuin luontoa palautumatta kumpaankaan. (Gibson 1979, 129; ks. myös Rose 2010, 29; Lehmuskallio 2012.) Kyse ei ole vain siitä, että inhimilliset toimijat käyttävät erilaisia objekteja tarpeiden mukaan. Valokuvan materiaalinen ydin on tarjouma, joka voi merkityksellistyä lukemattomilla tavoilla erilaisissa kulttuurisissa käytännöissä, mutta kaikkiin käytäntöihin se kantaa mukanaan läsnäolon-poissaolon-dynamiikkansa.

Esimerkiksi uutisvalokuvien materiaalinen ydin tekee itse kuvatun tapahtuman materiaalisesti läsnäolevaksi: kuva on todiste paikallaolosta. Tätä läsnäoloa kuitenkin rikkoo valokuvien luonne representaationa, joka faktisesti irrottaa katsojan tapahtumasta ja suo hänelle mahdollisuuden tarkastella ja "osallistua" katastrofiin turvallisesta tarkkailijan asemasta käsin. Materiaalisen ytimen mukanaan tuoma läsnäolonpoissaolon-dynamiikka uuttaa koko ajan esiin kysymyksiä valokuvan epistemologiasta ja esimerkiksi uutisvalokuvien mahdollistamasta tirkistelystä inhimillisen tragedian yksityiskohtiin.

\section{Valoisa huone ja materiaalinen ydin}

Valokuvan materiaalisen ytimen aiheuttama läsnäolon-poissaolon-dynamiikka ja representaation epävakaus sisältää myös paljon energiaa, joka voidaan kääntää valokuvan voimaksi, kyvyksi vastustaa signifikaatiota ja merkitysten sulkeumia. Roland Barthesin viimeiseksi jäänyt kirja, Valoisa huone (1980, suom. 1985), on oivallinen esimerkki. Teosta on tutkittu uupumukseen saakka, mutta se jaksaa yhä inspiroida tutkijoita (esim. Shawcross 1997; Elkins 2007; 2011; Batchen 2008; 2011a; 2011a; 2011b; 2011C; Yacavone 2012; Kella 2014). Barthes kirjoitti tekstin nopeasti, vain 49 päivän aikana, pääosin toukokuussa 1979 (Batchen 2011b; Barthes 1980, 184). Kirja jakautuu kahteen osaan, joissa kummassakin on 24 numeroitua pientä alalukua. Teoksen kertoja operoi yksikön ensimmäisessä persoonassa, mutta on mahdoton sanoa, onko kertoja teoksen kirjoittaja vai kirjoittajan teokseen luoma kerronnallinen positio (ks. esim. Burgin 2011, 2). Siksi erotan toisistaan teoksen kirjoittajan ja tekstin kertojan.

Teoksen kirjoittamista edeltävänä vuotena (1978) Barthes ilmaisi College de Francen luennossaan tavoittelevansa uudenlaista otetta kirjoittamiseen: "Asemoin itseni sellaiseen subjektipositioon, joka tekee jotain eikä enää vain puhu jostakin. En tutki lopputuotetta, vaan asetun osaksi prosessia." (Op. cit. Shawcross 1997, 72.) Valoisa huone ei ole pelkästään Barthesin kirjoittama analyysi, se on osa hänen valokuvallista 
kokemustaan. Tekstin poeettiset ratkaisut, kertojan ääni ja muut kirjalliset keinot ovat sekä valokuvan analyysiä että valokuvallisen kokemuksen välittämistä lukijalle. Kohtaaminen materiaalisen ytimen kanssa esiintyy tekstissä monin tavoin, mutta tässä keskityn kahteen piirteeseen: teokseen ajallisiin ja tilallisiin siirtymiin sekä niin sanottuun reaaliseen. ${ }^{11}$

Ajalliset ja tilalliset siirtymät ovat valokuvan materiaalisen ytimen liikkeen keskeisiä piirteitä. Valokuva piirtyy fotonien vaikutuksesta ajassa ja tilassa. Tämä jälki siirtyy toiseen aikaan ja tilaan, joskus hyvin monimutkaisten välitysten kautta. Monet henkilökohtaiset, kulttuuriset ja historialliset tekijät tietenkin vaikuttavat siihen, miten tämä siirtymä lopulta muotoutuu valokuvalliseksi kokemukseksi, mutta sen olemassaoloa on vaikea kiistää. Juuri tähän Barthesin kertoja viittaa, kun hän puhuu referentin itsepintaisesta läsnäolosta, "Tämä-on-ollut" (Barthes 1985, 83; 1980, 120). Kertoja (1980, 94-95; 1985, 138-139) myös sanoo kuuluvansa "realisteihin", mutta sellaisiin, jotka "eivät pidä valokuvaa todellisuuden 'kopiona', vaan pikemminkin menneen todellisuuden emanaationa: magiana, ei taiteena". Tästä syystä hänen mielestään on toisarvoista kiistellä siitä, kuinka tarkasti se visuaalisesti vastaa kuvauksen kohteen piirteitä.

Teoksen painopiste muuttuu, mikä näkyy punctumin käsitteen teoreettisessa siirtymissä. Kirjan ensimmäisessä osassa käsite viittaa valokuvien arkisista merkityksistä (studium) poikkeaviin häkellyttäviin visuaalisiin yksityiskohtiin: "Latinan kielessä on sana kuvaamaan tätä haavaa, tätä pistosta, tätä terävän esineen tekemään jälkeä", ja "tätä toista, studiumia häiritsevää osatekijää, kutsun punctumiksi [- - ]. Valokuvan punctum on se sattuma, joka pistää minua (mutta myös ruhjoo ja kirvelee sisälläni)." (Barthes 1985, 32-33; 1980, 49.) Kirjan toisessa osassa kertoja ei hylkää aiempia merkityksiä, mutta sanoo: "tiedän nyt, että 'yksityiskohdan' ohella on olemassa toinenkin punctum (toinenkin 'stigma'). Tämä uusi punctum ei enää muotoon vaan intensiteettiin liittyvä on aika, noeman ('se-on-ollut') raateleva paino, sen puhdas esitys" (1980, 102; 1985, 148). Nyt valokuva materiaalisena jälkenä on menneisyyden merkitsemä ja tämä "puhdas esitys" kasvaa eräänlaiseksi läsnäolon-poissaolon magiikaksi, joka kytkeytyy monin tavoin kysymykseen ajasta ja katsojan valokuvallisesta kokemuksesta. Materiaalinen ydin kohtaa katsojan ruumiillisuuden rikkaaseen metaforiikkaan pukeutuneena:

Valokuva on kirjaimellisesti referentin emanaatiota. Todellisesta, läsnä olleesta ruumiista virtaa säteilyä, joka lopulta koskettaa minua, joka olen tässä: siirtymisen ajallinen kesto ei merkitse mitään; kuvatun henkilön valokuva koskettaa minua samalla tavoin kuin jonkin tähden matkalla viipyneet säteet. [- -] Jonkinlainen napanuora liittää valokuvatun esineen minun katseeseeni: valo, vaikkakin käsin koskematon, on tässä hyvin ruumiillinen välittäjä, kuin jonkinlainen valokuvatun kanssa jakamani iho. (Barthes 1985, 86-87; 1980, 126-127)

Kirjan kertoja liikkuu valokuvan materiaalisuuden ytimessä, jossa filmille tai kuvakennolle piirtynyt jälki operoi sanallisten ja selkeiden merkitysten ohitse, ruumiillisen kosketuksen kautta. Barthesin retoriikka ei niinkään kiteytä valokuvan signifikaatiota 
kuin sen tarjoaman välittömän kokemuksen kuvan katsojalle. Hän kirjoittaa yhteydestä ja läsnäolosta, kuvauksen kohteen kanssa jaetusta "ihosta" tai katsojaa siihen yhdistävästä "napanuorasta". Vaikka tämä yhteys onkin hyvin materiaalinen ja läsnäoleva, valokuva itsessään on otettu toisessa ajassa ja paikassa, mikä saattaa valokuvan edustamaan myös absoluuttista poissaoloa.

Läsnä- ja poissaolon dynamiikka johtaa valokuvallisen representaation tilaan, jossa kuvan katsojalle avautuu mahdollisuus kohdata jotain, mitä psykoanalyytikko Jacques Lacan nimittää reaaliseksi. Valoisa huone avautuu reaalisen suuntaan erityisesti Tuchén käsitteen kautta. Lacan käsittelee sitä yhdeksännen seminaarinsa viidennessä luvussa, joka on otsikoitu "Tuché and Automaton" (Lacan 1986). Kummatkin käsitteet juontuvat Aristoteleen fysiikasta, mutta Lacan antaa niille omat merkityksensä. Tuché merkitsee "reaalisen kohtaamista" ja Automaton puolestaan "merkitsijöiden verkostoa" (Lacan 1986; ks. myös Iversen 2011, 59; Kella 2014, 223). Valoisan huoneen kertojalle Tuché viittaa valokuvan kykyyn tuoda esiin sellaista, mikä on esiintynyt vain kerran ja viittaa valokuvan singulaariseen, ainutkertaiseen olemiseen. Jokainen valokuva on "Tuché, Tilanne, Kohtaaminen, Todellisuus uupumattomassa ilmaisussaan" (Barthes $1985,10 ; 1980,15)$.

Tuchén merkityksiä tavoittaa avaamalla käsitettä Lacanin kolmen kuuluisan psyykkisen rekisterin kautta: imaginaarinen, symbolinen ja reaalinen (Lacan 1977; 1986, passim.). Ne kaikki ovat toisiinsa lomittuvia mielen kerrostumia ja toimintoja, joiden kautta subjekti asettuu osaksi maailmaa, merkityksiä ja kulttuuria.

Imaginaarinen saa alkunsa jo varhain, kun lapsi alkaa visuaalisesti samastua itsensä ulkopuolisiin kohteisiin, tavallisesti äitiinsä. Myöhemmin imaginaarinen liittyy muun muassa siihen, millaisia fantasioita ja kehollisia malleja, figuureja ja ideaaleja subjekti tuntee "omakseen". Imaginaarisessa identifikaatiossa on aina kyse samastumisesta toiseen - joko todellisiin ihmisiin tai representaatioihin ja se saa alkunsa jo ennen kielen omaksumista. Imaginaarisilla identifikaatioilla subjekti tavoittelee yleensä eheyden ja kokonaisuuden kokemuksia, vaikka jääkin aina niistä vajaaksi. Imaginaarinen on siis myös halun ja fantasian aluetta: esikuvien tavoittelua.

Symbolisen toiminnasta on kyse silloin, kun subjekti esimerkiksi kasvaa osaksi kieltä ja kulttuurin normaaleina pitämiä merkityksiä. Kieleen kasvaminen on sen merkitysten omaksumista, jotka ovat suhteellisen vakaita. Samalla tavoin symbolisen alueeseen kuuluvat visuaaliset näyttämöt ja kuvat, jotka ovat luonnollisia, ymmärrettäviä, avautuvia. Jos käytämme Valoisan huoneen käsitteitä, valokuvan studium on nimenomaan symbolisen aluetta: voimme nimetä valokuvista erilaisia tavanomaisia ja normaaleita asioita. Tämä on myös automaton, lacanilainen merkitsijöiden verkosto.

Reaalinen on puolestaan jotain sellaista, joka vastustaa niin symboliseen järjestykseen siirtymistä kuin eheyden tunteeseen liittyviä imaginaarisia identifikaatioita. Reaalinen häiritsee. Sitä ei voi tavoittaa nimellä. Tästä näkökulmasta Valoisan huoneen kummatkin punctumit (valokuvan yksityiskohta sekä emanaation tuottama ajan kokemus) liikkuvat reaalisen alueella ja ovat siis "Tuché". Lacanilla reaalinen on aina myös kuoleman, pelon ja trauman aluetta, koska se uhkaa romahduttaa subjektin imaginaariset eheyden kokemukset. Reaaliseen kuuluu (psyykkisen) hajoamisen tunne, jonka 
pohjalla vaanii kuolemanpelko. Tätä pelkoa hallitaan erilaisten minän puolustuskeinojen avulla.

Ei siis ihme, että Barthes valjastaa Tuchén käsitteen kirjaansa, joka on niin monin tavoin sekä konkreettisen (kirjailijan äiti) että vertauskuvaannollisen (valokuva muistutuksena kuolevaisuudesta) kuoleman läpitunkema. Valokuva imaginaarisen eheydentunteen ylläpitäjänä ei kiinnosta Barthesia sen enempää kuin vaikkapa tätä tunnetta hyväksi käyttävien valokuvien kritiikkikään. Hän ei ole kiinnostunut esimerkiksi siitä, miten mainosvalokuvien imaginaariset merkitykset antavat niiden kokijalle eheyden tunteita ja liittävät valokuvat symbolisella tasolla erilaisten ideologioiden toimintaan. Symbolinen itsessään on puolestaan studiumin, jaettujen, itsestään selvien ja opittujen merkitysten aluetta, jonka läpikäymiseen Valoisan huoneen kertoja ei aikaansa uhraa.

Reaalisen tavoittaminen kielellisesti on hyvin vaikeaa, oikeastaan mahdotonta. Sen voi kuitenkin aistia kirjan poeettisessa kielessä, joka yrittää puhutella tiedostamatonta symbolisten ja imaginaaristen rekisterien ohitse. Tästä syystä Valoisan huoneen kertoja on niin hämmentävä ja horjuttaa lukijan halua saada kaapatuksi eheitä, kokonaisia, selkeitä merkityksiä. Keskeisin tällä tavoin toimiva paradoksi liittyy juuri punctumiin, jonka kirjan kertoja kuitenkin nimeää vaikkei sitä hänen mukaansa voi nimetä. Valoisan huoneen kertojalle nimeämisen halu on eräänlaista pakoa signifikaatioon tilanteessa, jossa jokin merkityksen ja ymmärryksen reunoilla oleva uhkaa subjektia. Pohjimmiltaan nimeäminen on siis minän puolustusreaktio, sisäisen tai ulkoisen todellisuuden muodostaman uhan torjunta.

Jos ajatellaan, että Barthesilla reaalisen käsite viittaa nimenomaan kuoleman mahdollisuuteen ja eksistenssiä uhkaavaan merkityksen murenemiseen, niin kysymys kuuluu: miten valokuvan materiaalinen ydin kytkeytyy tähän prosessiin? On aivan liian yksinkertaista ajatella, että materiaalinen ydin on reaalinen, vaikka se onkin vaikeasti nimettävissä. Materiaalinen ydin ei ole reaalinen sen enempää kuin mikään materiaalisen todellisuuden osa. Olennaista on, että materiaalisen ytimen liike saattaa valokuvallisen representaation epävakaaseen tilaan, jossa kuvan katsoja ei voi koskaan olla varma, katsooko hän esitystä vai kuvauksen kohdetta itseään. Tällöin materiaalinen ikään kuin valuu symbolisen alueelle, hämmentää sitä, aiheuttaa epäterävyyttä. Materiaalisen ja symbolisen kohtaamisessa avautuu kokemuksellinen tila, jota ei voi selkeästi merkityksellistää ja jossa läsnä- ja poisaolo sekoittuvat toisiinsa.

Barthesin katsannossa emme voi välttää reaalisen kosketusta (Tuché) juuri tämän representaation paradoksaalisuuden vuoksi. Tämä puolestaan laittaa tekstin kertojan etsimään sitä, mikä valokuvassa koskettaa selkeän merkityksenannon ohitse tai tuolla/ tuolle puolen. Valoisassa huoneessa Barthes rakentaa siis valokuvasta paradoksaalisen "tutkimuskohteen", jossa valokuva semioottisena merkityksen kantajana ja merkityksellisenä materiaalisena jälkenä asettuvat jännitteiseen suhteeseen. Valokuvan epäämätön materiaalisuus elää metaforisen kuvailun rinnalla, josta muodostuu retorinen keino tavoittaa itse materiaalisuus. Raskas ja kevyt kohtaavat ja muuttuvat toisikseen.

Jos ajatellaan, että materiaalinen ydin itse asiassa ajaa valokuvallisen representaation epävakaaseen tilaan, teoksen kertoja on selvästi materian, ruumiin ja lihan puolella pohtiessaan pitäisikö meidän ymmärtää valokuva epävakaaksi "hulluksi" vai kult- 
tuuristen merkitysten ja koodien "kesyttämäksi". Niinpä Barthes päättääkin kirjansa (emt., 125) jättämällä lukijan pohtimaan vielä yhtä ristiriitaa: "Sellaiset ovat valokuvan kaksi tietä. Valinta on minun: joka alistan sen näkymän täydellisen illuusion sivilisoidulle koodille tai sitten kohtaan siinä itsepintaisen todellisuuden heräämisen."

Lukija jää kuitenkin miettimään, millaista on Barthesin, kirjan kertojan tai lukijan itsensä vapaus toimia materiaalisen ytimen kanssa. Valoisaa huonetta lukiessa alkaa hiljalleen vaikuttaa siltä, että materiaalinen ydin tunkee itseään vastustamattomalla voimalla valokuvateorian piiriin ja pakottaa sen mukautumaan itseensä, sen välittömään ja lihalliseen olemassaoloon. Onko Valoisa huone siis valokuvan tekstuaalinen haltuunotto vai itse asiassa oire valokuvan materiaalisen ytimen toimijuudesta, sen kyvystä muotoilla valokuvan teoreettinen diskurssi vastaamaan itseään?

\section{Viitteet}

1 On toki paljon muitakin kuvia, jotka syntyvät sähkömagneettisen säteilyn aiheuttamien materiaalisten muutosten seurauksena: fotogrammit, tutkakuvat ja jopa rusketusraidat iholla. Sen lisäksi tietokoneen sisään voidaan ohjelmoida virtuaalinen kamera, jolla on mahdollista ottaa "valokuvia" yhtä virtuaalisista objekteista. Tässä artikkelissa en ole kuitenkaan kiinnostunut näistä kuvallisuuden lajeista, koska ensin mainittuja kuvia ei oteta kameralla ja virtuaalinen kamera ei ole kamera vaan algoritmi. Sitoudun siis tervejärkiseen kantaan, jonka mukaan valokuvan tulee olla digitaalisella tai analogisella kameralla otettu kuva. Kamera puolestaan on laite, jonka optinen toiminta olennaisin osin noudattaa klassisen camera obscuran periaatteita. Kameroita ovat tällöin esimerkiksi järjestelmäkamerat, vanhat palkkikamerat tai vaikkapa erilaisiin mobiilimedioihin ympätyt miniatyyrikamerat.

2 Käytän tässä Valoisan huoneen suomennosta. Laitan kuitenkin viitteet myös alkutekstiin, koska olen joissain kohden muuttanut suomennosta. Kiitän Aino Koskenniemeä osuvista suomennokseen liittyvistä huomioista.

3 Sanottakoon, että Barthesille valon jättämä jälki filmin pinnalla viittaa kausaaliseen yhteyteen kuvattujen kohteiden, kameran ja joskus myös kuvaajan välillä. Hän ei siis edusta naiivia epistemologiaa, jonka mukaan valokuva jollain tavoin vahvistaa tai todistaa valokuvatun näkymän oikean merkityksen. Hän vain toteaa, kuinka valokemiallisen prosessin kehittymisen myötä valokuvan ydinpiirre tai "noema" eli "Tämä-on-ollut" (tuli mahdolliseksi (Barthes 1985, 86; Barthes 1980, 126; ks. myös Furuhata 2009).

4 David Bate (2013) huomauttaa, kuinka digitaalisen kameran kuvakenno on vain yksi mahdollinen esimerkki sensoreista. Visuaalisten sensoreiden lisäksi on olemassa ääneen, liikkeeseen tai jopa tuoksuihin reagoivia sensoreita, jotka kaikki voivat olla tietokoneen "aistimellisia" ulokkeita. (Ks. myös Lehmuskallio 2014.)

5 Doyle, Victor ja Paquet (2009, 34) kirjoittavat digitaalisen datan säilyttämisen keskeisestä haasteesta. He korostavat, että data pitää pystyä säilyttämään autenttisena ja sen formaatti sellaisena, että se saadaan avattua myös tulevaisuudessa. (Ks. myös Hodge \& Anderson 2007.)

Harri Laakso (2003, 88-) käsittelee perinpohjaisesti peircelaista indeksisyyttä valokuvan kontekstissa. Hän myös erottelee toisistaan (emt., 102) indeksisyyden, indeksin ja indeksisen logiikan. Indeksisyys viittaa hänen mukaansa "ominaisuuteen", indeksi "artefaktiin". Indeksinen logiikka viittaa indeksin syntytapaan. Myös Henri van Lier (2007, 117-122) pohtii kiinnostavasti Peircen indeksisyyden käsitettä valokuvauksen kontekstissa.

7 Koska indeksisyys on sekä materiaalinen että kulttuurinen ilmiö, myös fotorealistiset kuvat, jotka näyttävät valokuvilta mutta eivät niitä ole, voivat herättää indeksisyyden tunnun. Kendall L. Walton (2010, 27-29) pohtii "superrealistisen" kuvan kokemista Chuck Closen kuuluisan akryylimaalauksen Big Self Portrait (1967-1968) avulla. Teos näyttää valokuvalta olematta valokuva. Waltonin mukaan katsojat säpsähtävät hetkellä, jolloin he tajuavat, etteivät katso valokuvaa. Hänen mukaansa suhteemme kuvaan muuttuu radikaalisti, kun tiedostamme sen todellisen laadun. Muutos on paljon perinpohjaisempi kuin jos olisimme luulleet kuvaa esimerkiksi etsaukseksi ja myöhemmin huomanneet, että kyseessä onkin tussipiirros. "Tunnemme olevamme jotenkin vähemmän 
'yhteydessä' Closeen, kun huomaamme, ettei teos olekaan valokuva. Jos kyseessä olisi häkellyttävä alastonkuva, hämmennyksemme voisi miedontua, kun huomaamme, ettei kyseessä ollut valokuva vaan maalaus", Walton (emt., 27) kirjoittaa. Hän selittää muutosta sillä, että valokuvassa näemme todellisen henkilön. Tämä tuntuma häviää, kun tajuammekin, että kyseessä on mahdollisesti fiktiivinen henkilö.

Walton ei pohdi asiaa pidemmälle, mutta periaatteessa voidaan rakentaa neljä eri asetelmaa:

1. Kuva, joka näyttää valokuvalta ja on valokuva.

2. Kuva, joka näyttää valokuvalta mutta ei ole valokuva.

3. Kuva, joka ei näytä valokuvalta mutta on valokuva.

4. Kuva, joka ei näytä valokuvalta eikä ole valokuva.

Valokuvan merkitysten ja merkityksellisyyden kannalta olisi tietenkin ensiarvoisen tärkeää tietää, miten nämä eri asetelmat toimivat osana valokuvallista kokemusta. Vastausta voisi hakea empiirisillä tutkimusasetelmilla, joita ei tiettävästi kuitenkaan ole tehty. Kysymys on ennen kaikkea siitä, milloin ja miten valokuvallinen tulkinta laukeaa ja avaa ovat valokuvalliselle kokemukselle.

8 Danien Rubinstein ja Katrina Sluis (2013) kirjoittavat valokuvallisen representaation kriisistä ja näkevät sen johtuvan ennen kaikkea valokuvan algoritmisesta luonteesta, joka tarkoittaa digitaalisen valokuvan matemaattista ja erilaisilla sovelluksilla työstettävää, binaarista olomuotoa. Perinteisen valokuvan algoritmisuus puolestaan tarkoittaa esimerkiksi prosessia, jossa latentti kuva kehitetään näkyväksi. Kummassakin tapauksessa valokuva viittaa sekä kuvattuihin kohteisiin että omaan algoritmisuuteensa. Toisin sanoen: "algoritmisuutensa" vuoksi valokuva on jo lähtökohtaisesti "kriisiytynyt" representaationa, mediumina, joka esittää vain kuvauksen kohteita. Sen sijaan että näkisivät valokuvallisen representaation kriisin johtuvan materiaalisen ytimen liikkeistä, Rubinstein ja Sluis paikantavat sen representaatioon itse itseensä viittaavana prosessina. Tulkinta sopii hyvin yhteen kvanttifysiikasta tutun ajatuksen kanssa, että partikkelien maailmaa ei pysty havainnoimaan ilman havainnoijan vaikutusta havainnoinnin kohteeseen (ks. esim. Kallio-Tamminen 2008, 130).

9 Maynard on itse asiassa kirjoittanut artikkelinsa keskustelumuotoon kolmen naisen kesken (ks. myös Maynard 1997, 228).

10 Gibsonin ajatukset tarjoumista liityvät hänen yleisempää teoreettiseen näkemykseen visuaalisesta havaitsemisesta. Affordanssin käsite juontuu Kurt Koffkan hahmopsykologiasta ja Kurt Lewinin ajattelusta (Gibson 1979, 138-139; käsitteen ongelmista ks. esim. May 2009).

11 Olen käsitellyt Barthesin suhdetta valokuvan materiaalisuuteen ytimeen laajemmin kirjassani Levoton valokuva (Seppänen 2014).

\section{Kirjallisuus}

Ahmed, Sara (2008). Open Forum Imaginary Prohibitions: Some Preliminary Remarks on the Founding Gestures of the 'New Materialism'. European Journal of Women's Studies 15:1, 23-49.

Appadurai, Arjun (2006). The Thing itself. Public Culture 18:1, 15-21.

Appadurai, Arjun (1986). The Social Life of Things : Commodities in Cultural Perspective. Cambridge: Cambridge University Press.

Auyang, Sunny Y. (1995). How is Quantum Field Theory Possible? New York: Oxford University Press.

Barker, Chris (2004). The Sage Dictionary of Cultural Studies. London: Sage.

Barthes, Roland (1980). La Chambre Claire: note sur la photographie. Paris: Gallimard.

Barthes, Roland (1985). Valoisa huone. Suom. Martti Lintunen, Esa Sironen ja Leevi Lehto. Helsinki: Kansankulttuuri.

Barthes, Roland (1977). Image, Music, Text: Essays. London: Fontana.

Batchen, Geoffrey (1997). Burning with Desire: The Conception of Photography. Cambridge: MIT Press.

Batchen, Geoffrey (2008). Camera Lucida: Another Little History of Photography. Teoksessa: Kelsey, Robin E. \& Stimson, Blake (toim.). The Meaning of Photography. Massachusetts: Sterling and Francine Clark Art Institute, 76-91.

Batchen, Geoffrey (toim.) (2011a). Photography Degree Zero: Reflections on Roland Barthes's Camera Lucida. Cambridge, Mass.: MIT Press.

Batchen, Geoffrey (2011b) Palinode. Teoksessa: Batchen, Geoffrey (toim.). Photography Degree Zero: Reflections on Roland Barthes's Camera Lucida. Cambridge, Mass. \& London: MIT Press, 3-30. 
Batchen, Geoffrey (2011c). Another Little History of Photography. Teoksessa: Batchen, Geoffrey (toim.). Photography Degree Zero. Reflections on Roland Barthes's Camera Lucida. Cambridge, Mass. \& London: MIT Press, 260-273.

Bate, David (2013). The Digital Condition of Photography: Cameras, Computers and Display. Teoksessa: Lister, Martin (toim.). The Photographic Image in Digital Culture. 2. painos. New York: Routledge, 77-94.

Bazin, André (1960). The Ontology of the Photographic Image. Film Quarterly 13:4, 4-9.

Boivin, Nicole (2008). Material Cultures, Material Minds: The Impact of Things on Human Thought, Society, and Evolution. Cambridge: Cambridge University Press.

Brito Vieira, Mónica \& Runciman, David (2008). Representation. Key Concepts. Cambridge: Polity.

Coole, Diana H. \& Frost, Samantha (2010). New Materialisms: Ontology, Agency, and Politics. London: Duke University Press.

Deaux, Kay \& Philogène, Gina (2001). Representations of the Social: Bridging Theoretical Traditions. Oxford: Blackwell.

Doane, Mary Ann (2007). The Indexical and the Concept of Medium Specificity. Differences: A Journal of Feminist Cultural Studies 18:1, 128-152.

Doyle, Julie; Herna Viktor \& Paquet, Eric (2009). Long-Term Digital Preservation: Preserving Authenticity and Usability of 3-D Data. International Journal on Digital Libraries 10, 33-47.

Edwards, Elizabeth (2009). Photography and the Material Performance of the Past. History Q Theory 48: 4, 130-150.

Edwards, Elizabeth (2002). Material Beings: Objecthood and Ethnographic Photographs. Visual Studies $17: 1,67-75$.

Edwards, Elizabeth \& Hart, Janice (2004). Photographs Objects Histories : On the Materiality of Images. London: Routledge.

Edwards, Jason (2010). The Materialism of Historical Materialism. Teoksessa: Coole, Diana \& Frost, Samantha (toim.). New Materialisms: Ontology, Agency, and Politics. London: Duke University Press, 281-298.

Elkins, James (toim.) (2007). Photography Theory. New York \& London: Routledge.

Elkins, James (2011). What Photography is. New York: Routledge.

Furuhata, Yuriko (2009). Indexicality as "symptom": Photography and Affect. Semiotica 174: 1-4, 181-202.

Geimer, Peter (2007). Image as Trace: Speculations about an Undead Paradigm. Differences: A Journal of Feminist Cultural Studies 18: 1, 7-28.

Gibson, James J. (1979). The Ecological Approach to Visual Perception. Boston: Houghton Mifflin.

Giddens, Anthony (1984). The Constitution of Society: Outline of the Theory of Structuration. Cambridge: Polity.

Grosz, Elizabeth (2010). Feminism, Materialism, and Freedom. Teoksessa: Coole, Diana \& Frost, Samantha (toim.). New Materialisms: Ontology, Agency, and Politics. London: Duke University Press, 139-157.

Gunning, Tom (2004). What's the Point of an Index? Or, Faking Photographs. NORDICOM Review 25:1, 39-49.

Hall, Stuart (1997). The Work of Representation. Teoksessa: Hall, Stuart (toim.) Representation: Cultural Representations and Signifying Practices. London: Sage, 13-75.

Hahn, H. P. (2012). Words and Things: Reflections on People's Interaction with the Material World. Teoksessa: Maran, Joseph \& Stockhammer, Philipp (toim.). Materiality and Social Practice: Transformative Capacities of Intercultural Encounters. Oxford and Oakville: Oxbow Books, 4-12.

Hainge, Greg (2008). Unfixing the Photographic Image: Photography, Indexicality, fidelity and Normativity. Continuum: Journal of Media Q Cultural Studies 22: 5, 715-730.

Hall, Stuart (1997). The Work of Representation. Teoksessa: Hall, Stuart (toim.). Representation: Cultural Reprsentations and Signifying Practices. London: Sage Publications, 13-75.

Jacobson, R. E.; Ray, Sidney F.; Attridge, G. G. \& Axford, N. R. (2009). The Manual of Photography. Photographic and Digital Imaging. London \& Boston: Focal Press.

Kallio-Tamminen, Tarja (2008). Kvanttilainen todellisuus: fysiikka ja filosofia maailmankuvan muovaajina. Helsinki: Gaudeamus \& Helsinki University Press.

Keane, Helen \& Rosengarten, Marsha (2002). On the Biology of Sexed Subjects. Austalian Feminist Studies 17: 3, 261-277. 
Kella, Marjaana (2014). Käännöksiä: maisema, kasvot ja esittäminen valokuvassa. Helsinki: Aalto Arts Books.

Knuuttila, Tarja \& Lehtinen, Aki Petteri (2010). Representaatio: tiedon kivijalasta tieteiden työkaluksi. Helsinki: Gaudeamus.

Latour, Bruno (2005). Reassembling the Social : An Introduction to Actor-Network-Theory. Oxford: Oxford University Press.

Latour, Bruno (1993). We have Never been Modern. Cambridge, Mass.: Harvard University Press.

Lehmuskallio, Asko (2012). Pictorial Practices in a "Cam Era": Studying Non-Professional Camera Use. Acta Electronica Universitatis Tamperensis. Tampere: Tampere University Press.

Lier, Henri Van (2007). Philosophy of Photography. Käänt. Aarnoud Rommens. Leuven: Leuven University Press.

May, Michael (2010). Beyond Affordances - Why Direct Perception is Not enough in Design Engineering. Paper for CEPHAD (Centre for Philosophy \& Design).

Maynard, Patrick (1983). The Secular Icon: Photography and the Functions of Images. The Journal of Aesthetics and Art Criticism 42: 2, 155-169.

Maynard, Patrick (1997). The Engine of Visualization: Thinking through Photography. Ithaca: Cornell University Press.

Peirce, Charles S. (1965). Collected Papers of Charles Sanders Peirce. Vol. 1-2, Principles of Philosophy; Elements of Logic. Cambridge (Mass.): Belknap Press of Harvard University Press.

Pink, Sarah (2011). Sensory Digital Photography: Re-Thinking 'Moving' and the Image. Visual Studies 26: 1, 4-13.

Rose, Gillian (2010). Doing Family Photography: The Domestic, the Public, and the Politics of Sentiment. Farnham, Surrey, UK: Ashgate.

Seppänen, Janne (2014). Levoton valokuva. Tampere: Vastapaino.

Shawcross, Nancy (1997). Roland Barthes on Photography: The Critical Tradition in Perspective. Gainesville: University Press of Florida.

Snyder, Joel \& Allen, Neil W. (1975). Photography, Vision, and Representation. Critical Inquiry 2: 1, 143-169.

Sonesson, Göran (2001). The Pencils of Nature and Culture: New Light on--and in--the Lifeworld. Semiotica 136: 4, 27-53.

Sontag, Susan (1984). Valokuvauksesta. Suom. Kanerva Cederström ja Pekka Virtanen. Helsinki: Love kirjat.

Walton, Kendall (2010). Transparent Pictures: On the Nature of Photographic Realism. Teoksessa: Walden, Scott (toim.). Photography and Philosophy: Essays on the Pencil of Nature. Chichester: WileyBlackwell, 15-49.

Winston, Brian \& Tsang, Hing (2009). The Subject and the Indexicality of the Photograph. Semiotica 173: $1-4,453-469$.

Webb, Jen (2009). Understanding Representation. Thousand Oaks: Sage.

Yacavone, Kathrin (2012). Benjamin, Barthes, and the Singularity of Photography. New York: Continuum.

Žižek, Slavoj (1989). The Sublime Object of Ideology. London: Verso. 